\title{
Prospects of Mother Tongue as a Medium of Instruction in Nigerian Primary Level Education
}

\author{
Johnkenedy A. Ozoemena ${ }^{1}$, Festus U. Ngwoke ${ }^{2} \&$ Basil O. Nwokolo ${ }^{3}$ \\ ${ }^{1}$ The Use of English Unit, School of General Studies, University of Nigeria, Nsukka, Enugu State, Nigeria \\ ${ }^{2}$ Dept of English \& Literary Studies, University of Nigeria, Nsukka, Enugu State, Nigeria \\ ${ }^{3}$ Dept of English \& Literary Studies, University of Nigeria, Nsukka, Enugu State, Nigeria \\ Correspondence: Festus U. Ngwoke, Dept. of English \& Literary Studies, University of Nigeria, Nsukka, Enugu \\ State, Nigeria.
}

Received: December 22, 2020

Accepted: February 27, 2021

Online Published: March 3, 2021

doi: $10.5539 /$ elt.v14n4p1

URL: https://doi.org/10.5539/elt.v14n4p1

\begin{abstract}
This paper investigates the prospects in the use of mother tongue as a medium of instruction in Nigeria's primary level of education. With the multilingual nature of Nigeria, many scholars have continued to clamour for the use of indigenous languages as a medium of instruction in Nigeria's primary schools. This paper also seeks to justify the reasons why mother tongue education may not be feasible in the nearest future especially with the numerous roles that the English language plays in Nigeria, and the myriads of difficulties which constitute stumbling blocks to its realization. In doing this, two research questions were generated, and data collected from 150 primary school teachers, from both private and public primary schools in Gwagwalada Area Council of Federal Capital Territory (FCT) through purposive sampling technique. The instrument for data collection is a well-structured questionnaire. The questionnaire is made up of two sections, sections A and B. Section A sought for demographic data of respondents, while section B sought for information on the factors militating against mother tongue as a medium of instruction in primary schools in Nigeria. The data collected were analyzed using Crombatch Alpha, mean and standard deviation. The result of the analysis revealed that the multilingual nature of Nigeria, and lack of names of instructional materials and science equipment in the indigenous languages are impediments to the use of mother tongue as a medium of instruction in Nigerian primary level of education.
\end{abstract}

Keywords: mother tongue, prospects, primary level education, medium of instruction, crombatch alpha

\section{Introduction}

The importance of language in any human society cannot be over emphasized as it is of utmost importance in our day to day interaction which has ensured orderliness in society. Sequel to this Hall (1968) defines language as a situation whereby human beings communicate and interact with one another by means of habitually used oral, auditory, arbitrary symbols. In the same vein, Obanya (cited in Udensi, Ogbonnaya \& Ezema, 2018) opine that language is man's most important gift and maintained that language is a good instrument for thought and creativity (p. 27). Language is culture bound and is transmitted from generation to generation. History and culture have an overbearing influence on the language of a particular group of people; little wonder (Menon, Viswanatha, \& Sahi, 2014, p. 42) assert that "any discussion about language delves deeply into the history, politics, identities, imaginations and aspirations of a people". In the case of Nigeria, there are two sets of languages on which communication revolves: the native languages or the mother tongue with its numerous and distinct dialects and the English Language. Nigeria has an estimate of four hundred and fifty languages which are mutually unintelligible to each other, with Igbo, Hausa, and Yoruba as the three major languages and other languages such as: Tiv, Igala, Efik, Ebira, Jukun, Ijaw, etc. as the minor languages. The English language which was occasioned by colonialism right from the period of colonialism has been playing a vital role in Nigeria: first, as a language of commerce, later as a language of administration, education and wider communication. The assertions above reiterates the indispensability of language in any given society and as an instrument of thought, it is also a medium of transmitting knowledge. Education can only be transmitted through a language either local or foreign. Menon et al. (2014) corroborate this assertion and opine that:

In the case of Nigeria, education is transmitted through a foreign language owing to the nature of the type of 
education bequeathed to Nigerians by their colonial masters, and the multilingual nature of the Nigerian society, added to this is the exalted position and prestige accorded to the English language in the Nigeria society (p. 42).

Communication is the key to every human interaction in any society and can only be carried out through the instrumentality of a language with which the speaker and hearer share mutual intelligibility. The multiplicity of languages and dialects in Nigeria has completely hindered and hampered any acceptable indigenous language policy in Nigeria. This has made it mandatory that every aspect of Nigeria's national life revolves around the English language for the purpose of communication and social interaction. From the period of colonization to the period of independence in 1960, the English language has been playing vital roles in all facets of Nigeria's national life. It has been the language of instruction at all levels of education in Nigeria despite the Federal Government of Nigeria's National Policy on Education which states that "government will see to it that the medium of instruction in the primary school is initially the mother tongue or the language of the immediate community and at a later stage English" (Anyadiegwu, 2007, p. 30).

\subsection{Statement of the Problem}

There have been yearnings from some scholars few decades ago and even presently for the use of Nigeria's indigenous languages or mother tongue as the language of instruction at the primary school level of education. Chief among them is Nigeria's former Minister of Education, Professor, Babatunde Fafunwa. He has argued that children comprehend better when they are taught in the language of their immediate environment. This study, therefore, examines the possibility of using mother tongue as a language of instruction for science subjects in Nigeria's primary education taking into cognizance the myriads of factors that can hinder this system of education.

\subsection{Objectives of the Study}

The following are the objectives of this study:

1. To ascertain the opinions of 150 primary school teachers in the F.C.T., Abuja, on using mother tongue as a medium of education in Nigeria.

2. To identify the factors that can hinder the use of mother tongue as a language of instruction in Nigeria's primary school level of education.

3. To ascertain the possibility of teaching science subjects using the mother tongue as a language of instruction in Nigeria primary schools.

\subsection{Mother Tongue and Prospects of Mother Tongue Education in Nigeria}

The natural propensity and ability of every normal child to acquire and speak the language of his/her immediate environment at a certain age is called language acquisition device (LAD). This is an innate ability bestowed on any normal child from birth and this first language is called the mother tongue. It is the language which a child first learns in the process of communication. It is the language of the home in which the custom is transmitted and the characteristic parental and filial ties are laid (Taiwo as cited in Eruchalu, 2008, p. 183).

As stated earlier, language is culture bound, and is transmitted from generation to generation; so a speaker of any language as a first language or mother tongue possesses the greatest linguistic facility in that particular language which he uses to carry out his day to day activities. Olagboke (1979) avers that mother tongue is a language in which a child has acquired his first experiences of life, the one in which he dreams and thinks, and in which he can easily and conveniently express his feelings and emotions (p. 21). Aligning with the above assertions, Eruchalu (2008) posits that:

Linguists and psychologists believe that at the age of five every normal child has acquired a reasonable degree of competence in his native language. Noam Chomsky established a relationship between one's mind and the native language. To him a child has the ability to generate as many new grammatical sentences by applying the rules in his native language recursively. By the time the child is of school age, he has already learnt to form and mold his early (p. 51).

Abijo (2014) adds that "mother tongue education is the use of the native language or the first language to teach at formal and non formal levels" (p.124). Mackenzie \& Walker (2013) corroborate Abijo's view and state that children's potentials are often wasted when language acquisition is attempted without the use of native language which results in lack of development and educational failure. Fafunwa (1974) opines that mother tongue education is the systematic way of training and instructing a child through the medium of first language. $\mathrm{He}$ states further that it involves a formal approach which is the use of first language in teaching a child, or the use of mother tongue or native language as a means of formal education in schools. 
The United Nations Educational, Scientific and Cultural Organizations (UNESCO) is a strong advocate of mother tongue or first language as a language of formal education in early childhood and foundation education since 1953. This confirms the importance of mother tongue education to the development of any nation. Several scholars have also lent their voices on the need for first language education to the educational development of any given society. In Nigeria several studies have been carried out on the language of the immediate environment; one of such studies is the experiment on Nigeria's mother tongue education popularly known as the "Ife project" (Adedeji cited in Akindele \& Adegbite, 2004, p. 35).

40 teachers and educationists from the western part of Nigeria in a meeting held in Abeokuta Ogun State endorsed Fafunwa's mother tongue idea among other things. In a 13 point communiqué, they stated that the new language policy will, among other things, help the children understand and appreciate their cultural and democratic values, and also encourage them to contribute more meaningfully to the country's socioeconomic and political development. Sequel to this communiqué, the Ife project was carried out from 1974-1979. This was carried out to test the validity and workability of native language education in Nigeria. It was aimed at exploring the possibility of using mother tongue to teach all subjects in schools except foreign languages. About three thousand pupils were used for the Ife project. Three groups of schools were set up for the project; the first was the experimenter's school which serves as the model, and which used Yoruba language for formal instruction. The second group was named the control group, and English was used for the purpose of instruction. The third was named the traditional group and English was used for formal instruction but in a traditional way. At the end the project, organizers claimed that the experimenter group excelled all the others in all subjects and concluded that primary school children learn faster and better in all the school subjects when taught in the mother tongue (p. 82).

The Ife project is not embracive of the education policy of the Nigerian nation; the organizers based their mother tongue education experiment on only one linguistic group, the "Yoruba speaking part of Nigeria", and thus the project lacks a wide coverage. Nigeria is a multilingual country and a federation of thirty-six states and as such should have a unified education policy. The Ife project cannot be used as a yardstick for the validation of mother tongue education in Nigeria; hence it is not generally accepted/did not reflect a consensus education system. The organizers did not also take into cognizance the social problem and dislocation this system of regional based education can cause. For instance, a Hausa or Igbo speaking parents that reside in the Yoruba speaking part of Nigeria will have to relocate their children to their region of origin to acquire primary education. Also, most of the scientific concepts, if not all, have no names in all the Nigerian indigenous languages; it will take a long time for local names to be fashioned out. Added to this are the resources that will be expended to train teachers and produce new text books in the three major Nigerian languages: Igbo, Yoruba and Hausa which are considered as national languages in Nigeria. Corroborating this assertion, Taiwo (1980) avers that "Nigerian languages are rich in a traditional setting but deficient in expressing concepts, ideas, thoughts, skills and techniques which western education has introduced into modern Nigeria" (p. 183).

Ezeokoli and Ugwu (2019) studied parents', teachers' and students' beliefs about the use of mother tongue in the secondary schools in Akinyele Local Government Area of Oyo State. In the study, the researchers explored the beliefs of parents, teachers and students with respect to mother tongue usage as a means of instruction. The population of the study is 12 public senior secondary schools in Akinyele Local Government Area of Oyo State. 211 literate parents, 195 teachers and 237 SS I1 students were purposively selected. The finding of the study revealed that parents, teachers and students have a strong belief about the pedagogical and socio-cultural pertinence of native language education.

Igboanusi (2008) investigated mother tongue-based bilingual education in Nigeria: Attitudes and practice. The study population was 1000 respondents from five states of the Nigerian federation and data collection was through a questionnaire. The findings showed that the respondents preferred education in the English language to mother tongue.

Agbedo et al. (2012) carried out a study on mother tongue education in Nigeria which they entitled Mother Tongue Education as Agent of Decolonization: Implications for National Development. In the study, the researchers advocated a paradigm shift in the use of English as a means of formal instruction in the Nigeria's primary education system and insisted that the usage of native language for instruction in Nigeria's primary education will enhance national development.

All the studies reviewed above are either based on one linguistic group in Nigeria or did not represent a general education policy for Nigeria as a federation. Also none of the reviewed studies took into cognizance the factor that could hinder mother tongue education in Nigeria. Added to these factors is their lack of concern about the 
possibility of teaching science subjects in the mother tongue. This study intends to fill this gap in knowledge by sampling the opinion of five primary school teachers each from the three major linguistic groups in Nigeria: Igbo, Hausa and Yoruba. The reason is that these three languages are considered as national languages. The study will also investigate the factors that can hinder the use of mother tongue as a medium of instruction in Nigerian primary education, and the possibility of teaching science subjects in the mother tongue in Nigerian primary schools.

\subsection{English Language Roles in Nigeria}

The English language is a lasting legacy bequeathed to Nigeria and other Anglophone African countries by the British colonial masters. The genesis of the use of English in Nigeria started within the beginning of nineteenth century, when freed Nigerian native slaves returned to Nigeria sequel to the abolition of slave trade (Akindele and Adegbite, 2004, p. 33)

The English language will for a long time perform a pivotal role in Nigeria since no indigenous language has been acceptable to Nigerians as a national language, hence its continued status as the national language, the country's lingua franca and the language of wider communication. This fact is enunciated in paragraph 51 of the 1979 Nigerian constitution thus: All activities of the national assembly shall be carried out in English and in Igbo, Yoruba and Hausa until an adequate arrangement is made (as cited in Anyadiegwu, 2008, p. 29).

The English language, apart from being the official language of the government, is also the language of the mass media, both electronic and print media. It has also remained the language of formal instruction at all levels of education and in all the subjects and as well studied as a distinct subject. In fact, a credit pass in English has remained an indispensable condition for admission to study any course in Nigerian Universities, colleges of education and polytechnics. Besides this official role, it also performs some international functions. Akindele \& Adegbite (2004) summarize three roles the English language performs in Nigeria thus:

Accommodation: The English language is recognized as a world language as it performs numerous international functions. Firstly, it serves as a link between people of multilingual societies of Africa and the outside world. The English language is the language of international politics, trade and sports for instance at the O.A.U, U.N.O and the common wealth. Nigeria has no other language than English for taking part in the deliberations of these organizations. English also opens door to high technology, science, trade and diplomacy. Apart from these international functions performed by English, it serves as Nigeria's official language and the language of government business. It is also the language that people from different ethnic groups use to communicate with one another, English is also used as a matter of political expediency, its retention after independence is for the purpose of political stability in Nigeria this is as a result of the multiethnic nature of Nigeria, there is the need for a neutral language that will serve official purposes.

Participation: This function performed by English language in Nigeria enables people who desire to participate in the social, political, and economic life of the country, to do so with optimal knowledge. It is pertinent that these set of people know English very well. Proficiency in English is generally required for admission into the Parliament, the Bench and Bar, civil service and other essential services. English language is the medium of instruction at all levels of education in Nigeria.

Social Mobility: The English language enhances both horizontal and vertical mobility of people because of the obvious prestige associated with the language; hence a person is regarded as an illiterate for ones inability to speak English even if such a person is literate in his or her mother tongue. The English language is the language of institutions left behind by the colonizers, examples are: education, technology, administration, judiciary and executive, the business of all these institutions are largely conducted in English language (p. 64).

\subsection{Research Questions}

1. What are the factors that can hinder the use of mother tongue as a language of instruction in Nigeria primary level of education?

2. To what extent is the use of mother tongue feasible in teaching science subjects at the primary level of education in Nigerian?

\section{Theoretical Framework}

This study is hinged on Noam Chomsky's (1965) theory of language which stipulates that a child is born with an inherited capacity to acquire any human language. He invented the term "language acquisition device" (LAD) which he opines is innate in every child. By implication, LAD represents the key principles of a language with its grammatical structures. Every normal child becomes fluent in his or her native language within five or six 
years. Aligning with Chomsky's theory of language acquisition device, Pinker (as cited in Udensi, 2018, pp. 159-160) espouses this idea with that of universal grammar which is a set of innate principles and adjustable criteria that is common to all languages. Grammar is the law of language and all human beings are born with the innate propensity to understand these laws, since different languages may have separate grammars; human being have a natural tendency of learning and using them.

\section{Methods}

\subsection{Research Design}

The research design for this study is descriptive survey design.

\subsection{Population of the Study}

The population of the study includes all the primary school teachers in Gwagwalada Area Council of F.C.T.

\subsection{Sample and Sampling Technique}

The sampling size of the study is 150 teachers drawn from five public primary and five private primary schools in one of the Federal Capital Area councils, Gwagwalada through purposive sampling technique. The schools include: Madonna, International Nursery and Primary School, Christ Academy International Nursery and Primary School, Little Gems Montessori Nursery and Primary School, Al-Mohas Nursery and Primary School, Potter's Field Academy Nursery and Primary School, (private); U.B.E Primary School, Ungwar Dodo, Phase III Primary School, Pilot Primary School, Gado Nasko Primary School, U.B.E Primary School Paso, (public) all in Gwagwalada. The researchers employed this technique in the selection of 15 teachers: five Igbo teachers, five Yoruba teachers, and five Hausa teachers from each of the sampled schools in the said Area council. The reason for choosing teachers from the three major ethnic groups for the study is to factor out ethnic bias.

\subsection{Instrument for Data Collection}

The instrument for data collection for this study is a structured questionnaire titled: Mother Tongue Feasibility Study Questionnaire (M.T.F.S.Q) developed by the researchers. The instrument is made up of two sections A and B. Section A sought for the demographic information of the respondents, such as name of school, tribe, and gender while section B is made up of two clusters, clusters A and B. Cluster A comprises eight items which sought for information on the factors militating against mother tongue usage for instruction in primary schools in Nigeria, and cluster B consists of 4 items which sought information to ascertain the extent the use of mother tongue is feasible in teaching science subjects in primary schools in Nigeria.

\subsubsection{Validity of the Instrument}

The instrument for this research was validated by three experts, two linguists and one measurement expert, all from the University of Nigeria, Nsukka. Their valued suggestions and contributions were used to develop the final instrument.

\subsubsection{Reliability of the Instrument}

The M.T.F.Q was subjected to reliability analysis using Crombatch Alpha Statistics; hence the instrument was polytomously scored. Twenty copies of the final instrument were distributed to twenty teachers in Bwari Area Council of the F.C.T. The data collected were analyzed and used to establish the reliability coefficient of the instrument at 0.75 which proved that the instrument was reliable, in line with Nwaogu (2015) who opines that reliability of instrument ranging from coefficient of 0.5 and above is said to be reliable.

\subsection{Method of Data Analysis}

Data for this study were analyzed using mean and standard deviation. To answer research question one, the result was interpreted using the limit of real numbers, where a mean score of $1.00-1.49$ is regarded as Strongly Disagreed; 1.50 - 2.49 as Disagreed; 2.50 - 3.49 as Agreed; while 3.50 - 4.00 as Strongly Agreed. To answer research question number two, the result was interpreted using limit of real number where a mean score of 1.00 1.49 as very low extent; $1.50-2.49$ as low extent; $2.50-3.49$ as great extent, while $3.50-400$ as very Great Extent.

Research Question One: What are the factors that militate against the use of mother tongue as a language of instruction in Nigeria primary level of education? 
Table 1. Mean and Standard Deviation of Respondents on the factors that militate against the use of mother tongue as a medium of instruction in Nigeria primary level of education

$\mathbf{N}=\mathbf{1 5 0}$

\begin{tabular}{|c|c|c|c|c|}
\hline $\mathbf{S} / \mathbf{N}$ & Item Statement & $\bar{X}$ & SD & Dec \\
\hline 1 & $\begin{array}{l}\text { Multilingual nature of Nigeria affects the use of mother tongue as a language of } \\
\text { instruction }\end{array}$ & 3.25 & 0.93 & A \\
\hline 2 & $\begin{array}{l}\text { Prestigious position of English language in Nigeria affect the use of mother } \\
\text { tongue }\end{array}$ & 3.21 & 0.93 & A \\
\hline 3 & $\begin{array}{l}\text { First language of the teacher affects the use of mother tongue as a language of } \\
\text { instruction in Nigeria }\end{array}$ & 3.19 & 0.93 & A \\
\hline 4 & Intertribal marriage affect the use of mother tongue as a medium of instruction & 2.27 & 0.98 & $\mathrm{D}$ \\
\hline 5 & $\begin{array}{l}\text { Pupils from different ethnic groups in a class affect the use of mother tongue } \\
\text { based language of instruction }\end{array}$ & 3.24 & 0.97 & A \\
\hline 6 & $\begin{array}{l}\text { Dominance of instructional materials such as textbooks written in English } \\
\text { language affects the use of mother tongue as a language of instruction }\end{array}$ & 3.16 & 0.90 & A \\
\hline 7 & $\begin{array}{l}\text { Language of a child's immediate environment affects the use of mother tongue } \\
\text { as a language of instruction }\end{array}$ & 2.21 & 0.93 & $\mathrm{D}$ \\
\hline \multirow[t]{2}{*}{8} & $\begin{array}{l}\text { Occupational mobility of parents affect the use of mother tongue as a language } \\
\text { of instruction }\end{array}$ & 2.21 & 0.93 & $\mathrm{D}$ \\
\hline & Cluster mean & 2.84 & 0.94 & $\mathbf{A}$ \\
\hline
\end{tabular}

Key: $\mathrm{A}=$ agreed, $\mathrm{D}=$ Disagreed, $\mathrm{SA}=$ Strongly Agreed, $\mathrm{SD}=$ Strongly Disagreed

\section{Discussion of Findings (Research Question One)}

The findings of this study as presented in table 1 show the mean and standard deviations of respondents on the factors that militate against the use of mother tongue as a language of instruction in Nigeria primary level of education as measured by M.T.F.Q. The result of the study shows that the mean for item 1,2,3,5 and 6 , fall within the range of $2.50-3.49$ set as criterion for agreed; items 4, 7, and 8 fall within the range of $1.50-2.49$ set as criterion for Disagreed. The cluster mean of 2.84 with a standard deviation of 0.94 shows that the factors identified include:

(i) Multilingual nature of Nigeria affects the use of mother tongue as a medium of instruction. (ii) The prestigious position of the English language in Nigeria affects the use of mother tongue as a language of instruction, among other factors that affect the use of mother tongue as a medium of instruction in Nigeria primary school.

\subsection{Research Question Two}

To what extent is the use of mother tongue feasible in teaching science subjects at Nigeria primary level of education?

Table 2 Mean and Standard Deviation of Respondents on the extent to which the use of mother tongue is feasible in teaching science subjects at Nigeria primary level of education

$\mathbf{N}=\mathbf{1 5 0}$

\begin{tabular}{llccc}
\hline S/N & Item Statement: To what extent & $\overline{\boldsymbol{X}}$ & SD & Dec \\
\hline 1 & $\begin{array}{l}\text { Do new inventions in sciences affect the use of mother tongue as a language of instruction } \\
\text { in primary schools in Nigeria? }\end{array}$ & 3.25 & 0.93 & H.E \\
2 & $\begin{array}{l}\text { Does absence of local of names for science equipment in the mother tongue affect the use } \\
\text { of mother tongue as a language of instruction in Nigeria's primary level of education? }\end{array}$ & 3.21 & 0.93 & H.E \\
3 & $\begin{array}{l}\text { Does translation of scientific formulas affect the use of mother tongue as a language of } \\
\text { instruction in Nigeria's primary level of education? }\end{array}$ & 2.27 & 0.93 & L.E \\
$4 \quad \begin{array}{l}\text { Does the language of science text books affect the use of mother tongue as a language of } \\
\text { instruction in Nigeria's primary level of education? }\end{array}$ & 3.19 & 0.98 & H.E \\
& Cluster mean & $\mathbf{2 . 9 8}$ & $\mathbf{0 . 9 4}$ & H.E \\
\hline
\end{tabular}

Key: H.E = High Extent, L. E= Low Extent, V.L.E=Very Low Extent, V.G.E= Very Great Extent 


\subsection{Discussion of Findings (Research Question Two)}

The findings of the study as presented in table (ii) show the mean and standard deviation of the respondents on the extent to which the use of mother tongue is feasible in teaching science subjects in Nigeria's primary level of education as measured by the M.T.F.Q and revealed in the results of the study.

(i) The mean items 1, 2, 4 fall within the range of $2.05-3.49$ set as the criterion for high extent while item 3 fall within the range of $1.50-2.49$ set as the criterion for low extent.

(ii) The cluster mean of 2.98 with a standard deviation of 0.94 shows the extent to which new inventions in the sciences, lack of names of science equipment in the mother tongue, and the translation of scientific formulas can affect the use of mother tongue as a medium of instruction at Nigeria's primary level of education.

\subsection{Conclusion}

Based on the findings of this study, it is concluded that the prospects of using mother tongue as a language of instruction is not feasible in Nigeria at least in the foreseeable future. Hence, the research question one confirms, among others, that the multilingual nature of Nigeria hinders the effective use of mother tongue as a medium of instruction in Nigeria's primary level of education. Research question two also confirms, among other things, that the lack of names of instructional materials and science equipment in the mother tongue as well as lack of names of new scientific inventions in the mother tongue also hinders the use of mother tongue as a medium of instruction. In addition, considering the multi-lingual nature of Nigeria, out of the three major ethnic groups in Nigeria which are: Hausa, Igbo and Yoruba, none of these ethnic groups and the so called minority ethnic groups like: Tiv, Ebira, Ijaw, Jukun, Idoma, to mention but a few, will accept the imposition of any of the three major languages on them. Mother tongue education in Nigeria will bring about the mass production of new instructional materials and text books in the indigenous language of instruction as well as the training and recruitment of teachers in the adopted indigenous language of instruction. These will take several years of long term planning and experimentation before possible implementation.

\subsection{Recommendation}

This study recommends that policy makers in Nigeria should adopt a long term planning to fashion out a national language for the country which will replace English language as the nation's language of wider communication/official language and also serve as language of instruction in educational institutions in Nigeria.

\section{References}

Abijo, J. A. (2014). Emerging trends in the use of mother tongue as a language of instruction in lower Nigerian primary schools. Journal of Emerging Trends in Educational Research and Policy Studies, 5(8), 124-127.

Akindele, F., \& Adegbite, W. (1999). The Sociology and Politics of English in Nigeria: An introduction. Ile-ife: O.A.U Press.

Annual Report. (2004). Emerging voices: A report in education in South African communities.

Anyadiegwu, T. (2007). Principles and Methods of Teaching English as a second language. Onitsha: Auschalico Publishers.

Chomsky, N. (1965). Aspects of the theory of syntax. Cambridge: MIT Press. https://doi.org/10.21236/AD0616323

Eruchalu, G. (2008). Nigeria and mother tongue education. Awka. Journal of English Language and Literary Studies, 2, 188-192.

Laguarda, A., \& Woodward, W. (2013). They own this: Mother tongue instruction for indigenous Kuku children in Southern Sudan. School Psychology International, 34(4), 453-469. https://doi.org/10.1177/0143034312446893

Mackenzie, P., \& Walker, J. (2013). Global campaign for education policy brief: mother tongue education: policy lessons for quality and inclusion. Johannesburg: UNESCO. Retrieved from https://www.campaignforeducation.org

Menon, S., Viswanath, V., \& Sahi, J. (2014). Teaching in two tongues: Rethinking the role of language(s) in teacher education in India. Contemporary Education Dialogue, 11(1), 41-65. https://doi.org/10.1177/0973184913509752

Olagboke, D. O. (1979). The mother tongue and ESL in Nigerian education. In Ubahakwe (Ed.). Ibadan: University Press. 
Taiwo, C. O. (1980). The Nigerian education system past, present and future. London: Nelson Pitman.

Udensi, P. E., Ogbonnaya, K. A., \& Ezema, C. A. (2018). Indigenous language: A panacea to techno-industrial development in Nigeria.

UNESCO. (2010). Enhancing learning of children from diverse backgrounds: Mother tongue- based bilingual and Multilingual Education in early years. Paris: UNESCO.

\section{Copyrights}

Copyright for this article is retained by the author(s), with first publication rights granted to the journal.

This is an open-access article distributed under the terms and conditions of the Creative Commons Attribution license (http://creativecommons.org/licenses/by/4.0/). 